\title{
Exploring the link between irregular migration and asylum: the case of Italy
}

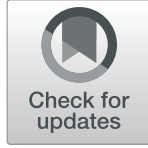

\author{
Daniela Ghio* and Gian Carlo Blangiardo
}

\author{
* Correspondence: dghio@yahoo.it \\ Università degli Studi di \\ Milano-Bicocca, Milano, Italy
}

\begin{abstract}
Many asylum seekers crossed European borders in an irregular manner during the last 2 years and completed their asylum procedure with a negative decision. Based on the limited number of effective orders to leave, it may be argued that a majority of rejected asylum seekers are de-facto staying in the European Union.

This paper aims to investigate the nexus between irregular migration and asylum. The analysis focuses on the case of Italy adopting a residual method. The amount of asylum seekers, who have the right of residence in Italy, is subtracted from the number of immigrants who entered Italian borders in an irregular manner from 2015 to 2017: the remainder amount provides an estimation of irregular immigrants generated by the failure of asylum procedure. A short-term migration scenario is settled for 2018 giving empirical-based insights to quantify irregular migrants who are likely to stay in Italy at the beginning of 2019.
\end{abstract}

Keywords: Irregular migrants, Asylum seekers

\section{Introduction}

Irregular migration is defined by reference to the rules of the national law, which establishes restrictions on entering and residing in the country (Tapinos 1999). Having a time dimension, irregularity may occur in different phases of migratory processes or be represented as a temporal experience during the migration cycle: migrants who have entered the country legally may reside illegally, and migrants who have entered the country clandestinely may change their status in a legal residence permit.

Irregular migration is linked with undocumented events and, for its inherent nature, is not covered by official statistics. Forcibly, irregular migration is derived from estimation using existing data. Yet, micro data on migration is rarely available and aggregated datasets are often fragmented, curbing the application of statistical techniques to eliminate biases. As a result, estimates of irregular migration have a larger margin of error, due to deficits in data and limitations in the application of methods. As explained by Tapinos (1999), the sole mean to achieve more accurate estimation is the comparison of results obtained using different statistical approaches. The project Clandestino gave an inventory and a critical appraisal of data and methods applied in the European Union, asserting that definitions and policies on irregular migration widely differ across the European Member States.

By contrast, asylum has been defined as better measurable than other forms of migration (Disney et al. 2005). Although differences at national level may persist, Eurostat

(c) The Author(s). 2019 Open Access This article is distributed under the terms of the Creative Commons Attribution 4.0 International License (http://creativecommons.org/licenses/by/4.0/), which permits unrestricted use, distribution, and reproduction in any medium, provided you give appropriate credit to the original author(s) and the source, provide a link to the Creative Commons license, and indicate if changes were made. 
data collections on asylum are significantly improved their harmonisation and accuracy since 2008, when the European directive on migration statistics entered into force.

Jandl (2004) conceptualises the differences between approaches and techniques of estimation of irregular migration: the author makes a distinction between a direct approach, which usually applies inference estimation technique on administrative sources or surveys, and an indirect approach, which usually applies residual methods using various and complementary data sources. Several empirical analyses have been carried out for measuring the stock of irregular migrants: the Department of Homeland Security yearly provides estimates of the unauthorised immigrant population residing in the United States by a residual methodology (Baker 2016). Papademetriou (2005) argues that irregular migrants represent at least $1 \%$ of the population of 25 European Member States, but figures grown at annual rates.

Other authors have investigated how migration policy restrictions affect the size of immigration flows (Czaika and de Haan 2014) and the number of asylum applications (Hatton 2011; Neumayer 2005). Massey and Pren (2012) claim that considering a long-term perspective, immigration policy has very little to do with trends and patterns of immigration.

Except for Czaika and Hobolth (2014), settling that in the period 2001-2011, a 10\% increase in asylum rejections raised the number of irregular migrants by an average about 3\% in 29 European states; few studies have deeply addressed the nexus between irregular migration and asylum systems.

The paper aims at the assessment of the unintended consequences of asylum procedure, under the legal framework of the Common European Asylum System. The analysis provides a systematic measurement of further irregular migrants that are retraceable from or back to the national asylum procedure, whereas failed asylum applicants cannot seek international protection in another European Member State.

An indirect approach is applied crossing official validated data with operational data collected by different actors involved in the migration management at national level. The empirical analysis focuses on the Italian asylum system. This case study appears to be particularly valuable for checking the proposed approach, given the fact that Italy, for its geographical location, is one of the main gates for several displaced persons escaping from Africa to reach the European Union in an irregular manner.

The paper finds at the end of 2018 from 467,000 to 634,300 immigrants would be added to the amount of estimated irregular migrants living in Italy at the beginning of 2015, due to the combined effects of new arrivals and asylum outcomes. Coherently with results achieved by different sources, it roughly implies that, under the hypothesis that no irregular immigrant leaves Italy during the observed periods, 10 out of 100 immigrants would stay in Italy irregularly.

The paper gives empirical-based insights to support migration management, accounting for national practices which are settled and pursued through the functioning of the national asylum systems. Whenever applied to a specific context, the method may be adjusted to quantify the effects of asylum procedure on the irregular migration across the European Union.

The proposed approach goes beyond the previous studies on irregular migration in the European Member States, which are commonly based on the analysis of 
specific events (i.e. border crossing or asylum decision), seizing different stages of asylum procedure, from the identification through the European database Eurodac, as the first registration of immigrants arrived in the European Union preventing from double lodgings of the same applicant over time in more national systems, to appeal, as second instance procedure. Accounting for the structural capacity of hosting countries to deal with migration trends, the analysis serves policy considerations for the application of solidarity principle in the Common European Asylum System, under circumstances of migration pressure.

The paper is structured as follows: after a first explanation of the adopted terminology, data and method are presented; then, main results from the empirical analysis are discussed. Finally, estimations are provided of what extend asylum inflows affect the stock of irregular migrants residing in Italy at the end of 2018.

\section{Defining the nexus between asylum and irregular migration}

Castle (2008) describes the asylum migration nexus as the blurring relationship between migration and asylum. To clarify the definition, a systematisation of terminology is needed.

The Convention n. 143 adopted by the 1975 International Labour Organisation Conference defines the illicit or clandestine movements of migrants as those where migrants find themselves during their journey, on arrival or during their period of residence and employment in conditions contravening relevant international multilateral or bilateral instruments or agreements, or national laws or regulations (Art.2 and Art.3).

The project Clandestino applied the term of illegal migration (Vogel and Jandl 2008), in its broadest sense as 'not legal' migration. Yet, Sciortino (2004) stressed that the term illegal migration could be systematically associated with criminal or otherwise illicit behaviours. In 1999, the Tampere Council conclusions referred to illegal migration, but more recently, the term irregular migration has been preferred to illegal migration, as reported by the European Agenda on Migration. ${ }^{1}$

The paper adopts the term of irregular migration, which appears to be gaining acceptance in international scientific researches (Pinkerton et al. 2004).

Two different situations of irregular migration are here distinguished under the legal framework of the Common European Asylum System: (1) entry without legal permission; (2) unauthorised stay after the issue of a negative asylum decision.

1. The European Member State responsible for the examination of the asylum claim is the Member State through which the asylum seeker first entered the European Union $^{2}$ : this implies that asylum seekers, who leave the European Member State where they firstly arrived, should be irregular migrants. ${ }^{3}$

2. Persons, who express their intention to apply for international protection, have the right to remain in the European Member State until the determining authority has made a decision ${ }^{4}$; if a negative decision is issued, the failed asylum seekers are ordered to leave the European territories: this implies that, except for those who appeal against negative a decision, rejected asylum seekers, remaining in the European Member States, should be irregular migrants. 


\section{Data}

No legal definition of irregular migrant is provided by the Italian legislation Immigration Act, but the Ministry of Interior gives the criteria for its assessment. ${ }^{5}$ The Ministry of Interior is also responsible for completeness, timeliness, accuracy, accessibility, transparency, comparability and dissemination of Italian migration data; statistics are shared with other institutions as part of the national statistical system coordinated by the Italian Institute of Statistics.

This empirical study is based on the following data sources:

1. Operational data on immigrants arrived in Italy, collected by the Ministry of Interior, Department of Public Security during rescue activities

2. Official statistics on asylum: administrative data on applicants and immigrants ordered to leave and effectively returned, collected by the Ministry of Interior, Police Headquarters (Questure), as decentralised bodies of the Department of Public Security; asylum decisions managed by the territorial commissions, as determining asylum authorities acting at local levels

Tapinos (1999) referred to the asylum system as a typical illustration of the limitations affecting the legal control of inflows and length of stay of immigrants. For a better understanding of the Italian asylum information system, the flow chart is here below shortly described (a block diagram schema is presented in the Additional file 1: Annex 1).

Italy, like some other Member States, has a regionalised approach to law enforcement and asylum, meaning that different phases of the asylum system are managed at different territorial levels: asylum applications are lodged by Questure, the first instance decisions are issued by Territorial Commissions and the second instance decisions are made by the local Courts. This approach, while offering potential efficiency gains due to the organisation of the state apparatus, by its nature raises harmonisation challenges. Similarly to the challenges faced at the European level, even slight differences in the application of national law, rules or procedures in local practice may exist.

Immigrants, who arrive in Italy by sea as part of a rescue operation, receive assistance and first medical screenings, before being accommodated in the emergency centres. ${ }^{6}$ The National Operation Centre, located in Rome, arranges the transfer to the hubs or directly to reception centres located in the Italian provinces. This distribution is based on available places according to the Protocol signed by the Italian Central Government and the Local authorities; during all phases of the process, immigrants are not detained. $^{7}$

When first assistance is completed, migrants are identified using the European database, Eurodac. The procedure consists of the fingerprinting and photographing: fingerprints are digitally recorded using the European standard format in order to check whether immigrants have already entered in the European or been registered as asylum seeker in another European Member States. If such a case is ascertained, immigrants are not double recorded and the Dublin procedure is activate for the determination of the European Member State responsible for taking in charge of immigrants.

For immigrants who express the intention to apply for international protection in Italy, the lodge of application should be formalised through Questure. The role of Questure is not to evaluate the application itself, but it is merely that of recording 
information about the asylum seekers' conditions (country of origin, reasons to leave, persecutions, violence and other elements that could be useful to support the request of international protection) into the information system, Vestanet. After the lodging of asylum application, a temporary residence permit is issued allowing asylum seekers the authorisation to stay in Italy. Competent authorities for examining the asylum requests and a first instance decision are the Territorial Commissions; against their decisions, rejected applicants have the right to submit, by a lawyer and within 30 days from notification, an appeal to the competent civil Court (ordinary tribunal under the territorial jurisdiction of the Territorial Commission). It should be noted that appeal produces the automatic suspensive effect of the order to leave the country.

As pointed out, unreliable data affect estimations (Aleshkovskiy 2014, Jandl 2004; Delaunay 1998); for regional system, like the Italian one, there is also the risk of many figures and little comprehension (the definition derives from Cyrus and Kovacheva 2009). Fragmentation in data collection may alter the performance of the system as a whole, when large numbers of arriving irregular migrants are concentrated in few local offices, generating unbalanced workloads and lack of capacity in specific contexts.

\section{Method}

Irregular migration cannot be statistically measured; the lack of observable events and regularities in the phenomena forces the adoption of methods for estimating irregular migrants (Tapinos 1999). First, methods developed in the USA were classified as residual, being irregular immigrants calculated by difference between the total of migrant population counted by census and the amount of foreign-born population registered in administrative data sources. Following this classification, a residual method is proposed for processing the above described datasets. Achieved results are then compared with estimations obtained through other sources for coherency validation.

\section{Estimation of irregular immigrant annual flows linked with asylum procedure}

1. The number of immigrants, who entered Italian borders in an irregular manner and have not applied for international protection in Italy is expected to be equal to

$$
E_{t}=A_{t}-S_{t}
$$

whereas:

$E_{t}$ Net irregular entries

$A_{t}=$ Irregular entries: immigrants who were rescued by Italian authorities during the reference year $t$ and were identified through Eurodac database as first time immigrants in a European Member State.

$S_{t}=$ asylum seekers recorded during the period $t$.

A compensation is assumed between immigrants arrived at time $t$, who were recorded as asylum seekers at time $t+1$, and asylum seekers recorded at time $t$, who arrived at time $t-1$.

2. Rejected asylum seekers, who were ordered to leave Italy but have decided to stay as irregular migrants 


$$
R a_{t}=N f_{t}-A p_{t}+N s_{t}
$$

whereas:

$R a_{t}$ is the rejected asylum applicants during the period $t$.

$N f_{t}$ is the negative decisions at the first instance issued during the period $t$.

$A p_{t}$ is the appeals against the first negative instance decision issued during the period $t$.

$N s_{t}$ is the negative decisions at the second instance issued during the period $t$.

Negative decisions at the first and second instances are counted (as difference between the total and positive decisions) for measuring rejected asylum applicants during the time $t$. Decisions are not necessary related to the applications lodged during the same time $t$. Yet, according to the European Regulation, asylum seekers are authorised to stay in Italy for the entire duration of asylum procedure: the length of asylum procedure should not be longer than 6 months. Negative decisions at first and second instance are respectively:

- Negative decision at first instance:

$$
N f_{t}=D f_{t}-D p f_{t}
$$

where $D f_{t}$ is the total decisions at the first instance; $D p f_{t}$ is the positive decisions at the first instance.

- Negative decision at second instance:

$$
N s_{t}=D s_{t}-D p s_{t}
$$

where $D s_{t}$ is the total decisions at the second instance; $D p s_{t}$ is the positive decisions at the second instance.

As examined by Czaika and Hobolth (2014) irregular asylum migration is linked with two decisions: (1) whether to apply for asylum: in the European context, Dublin legal statements force the decision on where to apply for asylum; (2) whether to stay or return in case of a negative decision. Therefore, the number of new irregular migrants, due to rejected asylum applicants during the period $t$, is derived by difference between the number of rejected asylum applicants and the number of rejected asylum applicants who effectively returned to their country of origin during the period $t$ :

$$
I a_{t}=R a_{t}-R e_{t}
$$

whereas:

$I a_{t}$ is the irregular asylum-related immigrants in the period $t$.

$R e_{t}$ is the returned rejected asylum applicants in the period $t$.

To calculate the increase of the stock of irregular immigrants in Italy at the end of year $t$, two hypotheses are formulated:

1. High impact hypothesis: all immigrants, who entered illegally Italian borders and did not apply for international protection in Italy, remain in the Italian territories during the period where effects generated by asylum-related flows $I a_{t}$ should be added to the irregular entries $E_{t}$ 
$I m_{t}=E_{t}+I a_{t}$

2. Low impact hypothesis: all immigrants, who entered illegally Italian borders and did not apply for international protection in Italy, left the Italian territories the period, therefore

$$
I m_{t}=I a_{t}
$$

\section{Comparison with other sources}

Experts have converged in considering the estimates provided by the ISMU Foundation, ${ }^{8}$ as the most accurate and reliable ones for Italy (Clandestino, Country Report Italy 2009). From the 1990s, Ismu has conducted surveys on immigrants, specifically designed to include those not formally registered or accounted for in official statistics, using an appropriate sample methodology (Baio and Blangiardo 2011); since 2001, an annual survey was carried out in Lombardy, and in 2005 and 2009, the sample method has been applied extending the regional survey to the national context. In 2005, the sample included more than 30,000 immigrants residing in Italy and in 2009 nearly 13,000 (these surveys were financed by the Ministry of Labour and Social Policies). A further national survey (12,000 units) was carried on in 2009 in 32 Italian provinces through a consortium of University research centres coordinated by the Ismu Foundation. Looking at Table 1, effects of regularisation measures adopted by Italian governments are evident in 2007, when the increase of regular population reflected the number of irregular migrants that obtained a regular residence permit through the quota admitted by the regularisation process. The effect should be combined with the impacts of the enlargement, which involved Romania and Bulgaria (Accession treaty signed on 25 April 2005). After the accession of these countries to the European Union, immigrants in Italy could not be considered as irregular residents anymore. Similarly, it can be observed in 2009, when around 200,000 requests of regularisation were submitted and the stock of irregular migrants dropped by $35 \%$, and in 2012, when the requests were not more than 130,000 and 26\% decrease of the stock was appraised.

At the beginning of 2015, the base year in this analysis, foreign population living in Italy reached the amount of 5,819,000 persons: According to the Ismu Foundation Report, the amount of 5,819,000 is composed by: 5,014,000 are regularly recorded in the Population Register (Anagrafe), 401,000 are regularly not residing in Italy and 404,000 are irregular. This implies that irregular migrants were expected to be 8 out of 100 .

Estimated flows of irregular immigrants from the analysis will be compared with the stock of irregular immigrants provided by ISMU Foundation to check coherency between results reached using different methods.

\section{Asylum flows and irregular migration in 2015-2016}

Asylum-related events occurred in 2015 are summarised using Table 2. The number of immigrants arrived in Italy was around $153,000,{ }^{9}$ but less than 84,000 of them applied for international protection (45 out of 100 immigrants did not apply for international protection in Italy). As explained above, immigrants should apply for international protection in the European Member State where they firstly arrived. These figures show 
Table 1 Source ISMU Estimations of irregular immigrants in Italy, 1991-2018

\begin{tabular}{llllll}
\hline Year & $\begin{array}{l}\text { Irregular Immigrants } \\
\text { Estimation }\end{array}$ & Year & $\begin{array}{l}\text { Irregular Immigrants } \\
\text { Estimation }\end{array}$ & Year & $\begin{array}{l}\text { Irregular Immigrants } \\
\text { Estimation }\end{array}$ \\
\hline 1991 & 383,000 & 2001 & 469,000 & 2011 & 443,000 \\
1992 & 293,000 & 2002 & 750,000 & 2012 & 326,000 \\
1993 & 323,333 & 2003 & 500,000 & 2013 & 294,000 \\
1994 & 353,667 & 2004 & 250,000 & 2014 & 350,000 \\
1995 & 384,000 & 2005 & 443,000 & 2015 & 404,000 \\
1996 & 262,000 & 2006 & 650,000 & 2016 & 435,000 \\
1997 & 140,000 & 2007 & 349,000 & 2017 & 491,000 \\
1998 & 245,000 & 2008 & 651,000 & 2018 & 533,000 \\
1999 & 249,333 & 2009 & 422,000 & & \\
2000 & 188,000 & 2010 & 454,000 & & \\
\hline
\end{tabular}

that immigrants arriving in Italy could ultimately try to choose other European Member States, offering them more favourable conditions of asylum and life or decide to stay in Italy living as irregular migrants.

Asylum seekers originated across a large set of countries: a vast majority from African countries, i.e. Nigeria, Gambia and Senegal, but also from Pakistan, Bangladesh and Ukraine. Fifty-eight out of 100 immigrants who submitted a request in Italy did not fulfil the requirements to obtain international protection (which corresponds to more than 41,000 negative decisions issued by the Territorial Commissions). However, half of rejected asylum seekers obtained a temporary suspension of the order to leave Italy as a consequence of the appeal procedure and around 14,600 appeals were accepted.

The framework is completed counting the effects of return measures adopted by the Italian authorities: 5500 immigrants were forced returned and 411 immigrants were assisted returned to their countries of origin.

Therefore, the stock of irregular migrants residing in Italy at the end of 2015 (Table 2, year 2015) is expected to increase by: (a) around 90,500 immigrants, when rejected asylum seekers plus immigrants who entered Italy in 2015 and did not apply for international protection, were stayed in Italy irregularly (apart from returned migrants, who were forced or voluntary assisted to come back to their country or origin); (b) around 22,000 immigrants, calculated as residual amount from (a) when immigrants who entered Italy in 2015 and did not apply for international protection were assumed to leave Italy. The hypothesis is verified by Eurostat Dublin statistics (Eurostat data collection on Incoming Dublin Requests by submitting country); in 2016, Italy recorded around 64,000 incoming requests.

In 2016, the immigrants who arrived in Italy were more than 181,400, representing the highest annual number of immigrants recorded since the beginning of the Arab Spring. The number of first-time asylum applicants was $123,600^{10}$; by difference, the amount of immigrants who did not apply for international protection in Italy was approximately 57,800 .

The term of asylum lottery is often used to suggest that asylum seekers may be motivated to apply in the country where the most attractive regime of protection is offered. Yet, there are several reasons for which a person may prefer a specific country: empirical studies have highlighted that asylum seekers' choice of destination is more 
Table 2 Summary of migration events occurred in Italy, 2015-2016 (data sources: Ministry of Interior) and estimated increase of irregular migrant stock due to new sea arrivals at the end of the

\begin{tabular}{|c|c|c|c|}
\hline Asylum procedure & Events & 2015 & 2016 \\
\hline \multirow[t]{3}{*}{ Identification } & Arrival and Eurodac check and registration & 152,428 & 181,436 \\
\hline & Lodging of application & 83,970 & 123,600 \\
\hline & Irregular immigrants after the identification procedure & 68,458 & 57,836 \\
\hline \multirow[t]{4}{*}{ First instance procedure } & Examination and decision & & \\
\hline & First instance total decisions & 71,345 & 91,102 \\
\hline & First instance positive decisions & 29,615 & 36,848 \\
\hline & First instance negative decisions & 41,730 & 54,254 \\
\hline \multirow[t]{5}{*}{ Second instance procedure } & Appeals against the first instance decision & 20,865 & 32,600 \\
\hline & Second instance decisions & 20,865 & 21,654 \\
\hline & Second instance positive decisions & 14,605 & 10,244 \\
\hline & Second instance negative decisions & 6,260 & 11,410 \\
\hline & Irregular immigrants after the second instance procedure & 27,125 & 33,064 \\
\hline \multirow[t]{3}{*}{ Return } & Forced, assisted and volontary returnees & 5,081 & 7,215 \\
\hline & Estimated Irregular immigrants flow during the period & 22,044 & 25,849 \\
\hline & Estimated impact on irregular migrant stock & & \\
\hline 1. Hypothesis High Impact & Irregular immigrants remain in Italy & 90,502 & 83,685 \\
\hline 2. Hypothesis Low Impact & Irregular immigrants leave Italy & 22,044 & 25,849 \\
\hline
\end{tabular}

determined by the network and the diaspora effects rather than other conditions. Thielemann (2006) fulfils "the little evidence for the claim that there is a systemic asylum shopping to exploit differences in host countries' welfare provisions".

The asylum lottery is confirmed: immigrants would prefer to take the risks to become irregular (moving to another European Member States or remaining the country) than to apply for international protection in Italy.

Territorial Commissions' decisions at first instance were more than 91,000; the rejection rate was $60 \%$, and it means that 54,254 asylum seekers were not granted by an international or humanitarian protection status. At the end of 2016, the estimated number of appeals submitted in Italy was 32,$600 ; 35 \%$ of them were rejected at second instance. More than 5700 immigrants were forced returned and 1500 immigrants were returned to their countries of origin through the Assisted Voluntary Returns and Reintegration projects implemented by the European Asylum Migration and Integration Fund. ${ }^{11}$

The implications of asylum flows on the stock of irregular migrants at the end of 2016 is expected to be around: (a) 25,800 additional immigrants (the failed asylum seekers at first and second instances who refused to leave Italy), under the hypothesis that all immigrants, who entered illegally Italian borders and did not apply for international protection in Italy, left the Italian territories in 2016; (b) 83,600 additional immigrants, assuming that both the rejected asylum seekers and the irregular immigrants who did not go through the asylum procedure, decided to live in Italy irregularly.

During the same year, Eurostat recorded more than 1,200,000 applications for international protection lodged ${ }^{12}$ in the European Union: the higher number of these 
applications mainly derives from migrants who have crossed European borders irregularly. ${ }^{13}$ In 2016, the European recognition rate at the first instance was $61 \%{ }^{14}$; analytically, 433,000 asylum seekers were rejected at first instance. However, including the number of apprehensions in the border regions, the number of persons ordered to leave the European Union was 493,000, whereas the number of immigrants effectively returned to their countries of origin was around 250,000. It is evident that, similarly to Italy, other European Member States, such as France, Belgium and Bulgaria, did not implement efficiently return policies addressed by the European Agenda on Migra$\operatorname{tion}^{15}$ : the ratio between the number of person effectively returned and the number of persons ordered to leave was not higher than $22 \%$. Computing effects of asylum flows at the end of 2016, the stock of irregular migrants residing in the European Union could be approximately increased by 200,000 additional rejected asylum seekers living in the European Union even though the restrictive legislation and administrative regulations that could limit their access to the national social protection systems and related forms of assistance.

\section{7-2018, a new scenario}

Whilst from January to June 2017 the amount of irregular immigrants arrived in Italy was higher compared with the same period in 2016, the annual inflow fallen by $34 \%$ compared to 2016. Immigrants mainly came from Nigeria (17\%), Guinea, Ivory Coast, Bangladesh (9\%), Mali and Eritrea (6\%). During the year, 130.100 asylum applicants were recorded; this higher number in comparison with immigrants rescued by the Italian and European Coast Guards primarily refers to the following countries of origin: Nigeria (20\%) Bangladesh, (10\%) Pakistan (7\%).

Differences could be explained by administrative and/or individual reasons. To exemplify, administrative reasons could consist of applications lodged by border offices (such as border points with France, Ventimiglia, and Switzerland, Como), in addition to applications lodged by Questure ${ }^{16}$; pursued implementation practices on the ground, or pending requests accumulated from past massive numbers of requests. Aida Report for Italy, 2017, documented obstacles in Questure, such as Naples Rome and Bari, with a specific calendar for registration procedures or that raised barriers on specific nationalities, which could not be in need of international protection (AIDA 2017). In some overcrowded Questure, delays in the formal lodging of application could have prolonged the condition of irregular status for some immigrants previously arrived. Yet, inefficiencies in the system should be compensated by the seasonal fluctuations of arrivals, as displayed by Fig. 1.

Individual reasons are linked with immigrants' behaviours: absconded migrants, likely arrived in 2016, could have decided to apply in Italy, being no legal provision to impose a time limit for filing the request before the Questure, when immigrants are already in Italian territory. This possible re-orientation toward the channel of asylum procedure could result from an underestimation of the risk to stay in Italy as irregular migrants and the hardship to reach another destination. In April 2017, Italian government adopted the Minniti-Orlando decree (D.L.12/2017) which expanded criteria for determining irregular status of immigrants that repeatedly refuse to be fingerprinted. Law 46/2017 also reduces the degrees of appeals, making appeal at third instance possible 


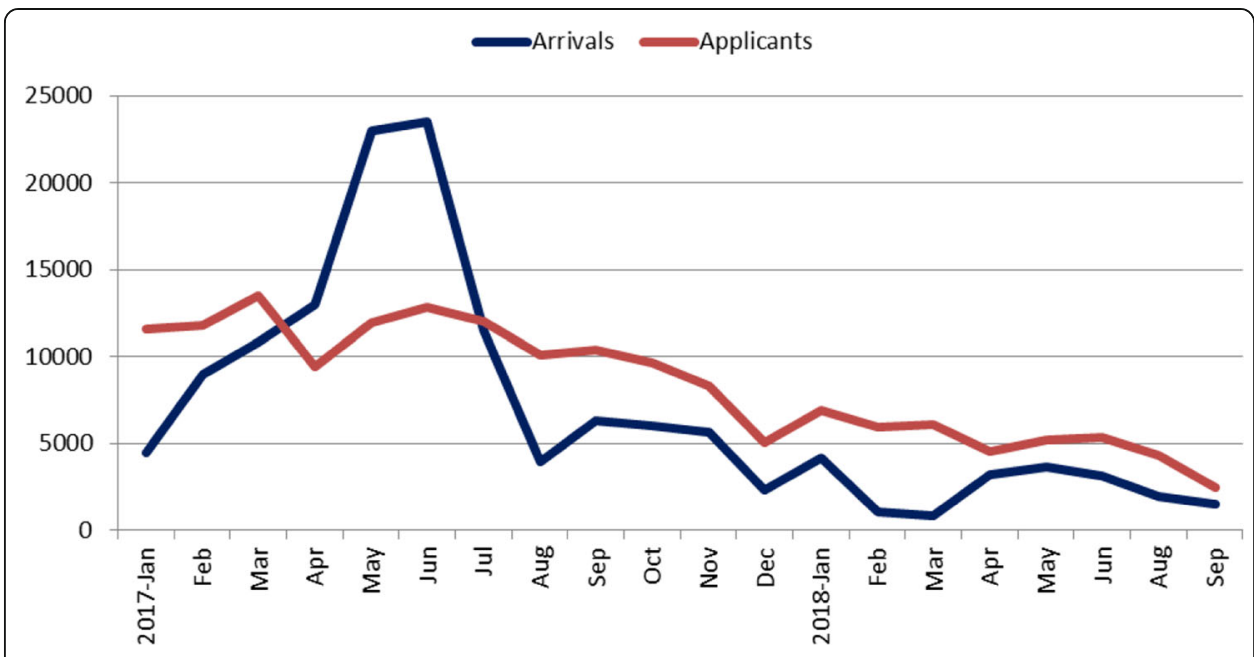

Fig. 1 Monthly arrivals and asylum applications in Italy, January 2017-September 2018

only through the Supreme Court. Asylum procedure was simplified introducing the use of videoconference in the interview of asylum seekers and allocating budget for the enforcement of return operations.

Rigorous applications of Dublin criteria involve the pushing back of immigrants when attempting to cross the borders, or coming back through Dublin procedure when applying for asylum in another European Member State. Looking at Eurostat statistics, Italy received 10.239 requests of taking in charge of immigrants that on the basis of proof or circumstantial evidence (..) have irregularly crossed the border into a Member State (as defined by Dublin Regulation Article 13.1) and 13.700 requests of taking back of immigrants who have already lodged an applications (Dublin Regulation Article 18.1) ${ }^{17}$

Yet, individual reasons may also depend on family and networks or be forced by smugglers, traffickers and other intermediates, taking into account that opportunities to choose other legal routes in alternative to the asylum one (i.e. to find a job) are realistically very limited. Finally, the case of immigrants who arrived in Italy with a legal entry and deflected into irregularity later could not be a priori excluded. These micro-meso effects are herein enumerated as macro estimation ${ }^{18}$ in the framework of asylum procedure implications.

In 2017, 81,000 decisions were issued by Territorial Commissions, with 58 out of 100 as rejected applicants, accounting for 47,000 negative decisions. To fill the lack of updated official statistics, estimations of appeals and second instance decisions are provided on the basis of past trends.

Although the European Council conclusions in October 2017 underlined the need of an effective action on returns and the intention of the European Commission to mobilise additional funds for helping Italian authorities in accelerating return procedures, only a relative increase of forced returns was recorded in 2017 (Table 3).

Implications on the stock of irregular migrants residing in Italy at the end of 2017 is expected to be composed by (a) 16,706 additional irregular immigrants under the hypothesis that absconded asylum seekers have decided to apply for international protection sorting out from an irregular status; (b) 27,456 failed asylum seekers, who refuse to leave the Italian territories and stay as irregular migrants. 
Table 3 Summary of migration events occurred in Italy, 2017 (data sources: Ministry of Interior); estimations related to 2018 events and the changes of irregular migrant stock due to new sea arrivals at the end of 2017 and 2018

\begin{tabular}{|c|c|c|c|}
\hline Asylum procedure & Events & 2017 & 2018 \\
\hline \multirow[t]{3}{*}{ Identification } & Arrival and Eurodac check and registration & 119,369 & 23,500 \\
\hline & Lodging of application & 130,119 & 53,735 \\
\hline & Irregular immigrants after the identification procedure & $-10,750$ & $-30,235$ \\
\hline \multirow[t]{4}{*}{ First instance procedure } & Examination and decision & & \\
\hline & First instance total decisions & 81,527 & 94,700 \\
\hline & First instance positive decisions & 34,535 & 35,039 \\
\hline & First instance negative decisions & 46,992 & 59,661 \\
\hline \multirow[t]{5}{*}{ Second instance procedure } & Appeals against the first instance decision & 16,448 & 34,006 \\
\hline & Second instance decisions & 16,448 & 34,006 \\
\hline & Second instance positive decisions & 10,691 & 22,104 \\
\hline & Second instance negative decisions & 5,757 & 11,902 \\
\hline & Irregular immigrants after the second instance procedure & 36,301 & 37,557 \\
\hline \multirow[t]{3}{*}{ Return } & Forced, assisted and volontary returnees & 8,845 & 8,845 \\
\hline & Estimated Irregular immigrants flow during the period & 27,456 & 28,712 \\
\hline & Estimated impact on irregular migrant stock & & \\
\hline 1. Hypothesis High Impact & Irregular immigrants remain in Italy & 16,706 & $-1,523$ \\
\hline 2. Hypothesis Low Impact & Irregular immigrants leave Italy & 27,456 & 28,712 \\
\hline
\end{tabular}

To examine 2018 trends, events occurred from January to September 2018 were accounted for settling monthly averages to provide estimations covering the annual period as whole.

In 2018, the decrease of migration trends started in July 2017 is confirmed. Observing that 43,900 immigrants have applied for international protection in Italy from January to September 2018, and assuming this trend as constant for the remaining months of the year, the yearly amount is quantified by 53,735 asylum applicants which thus implies a higher discrepancy between newly arrived immigrants and asylum seeker (around 30,200) in comparison with 2017, indicating that a significant number of asylum claims are potentially filed after illegally entering the country. As shown by Fig. 1, during the period January-September 2018, on average, ${ }^{19}$ one new immigrant arrived in Italy was counterbalanced by two asylum seekers registered by Questure.

Formulating the hypothesis that capacity of local authorities to manage administrative backlogs has efficiently improved, the decisions to apply for international protection could be predominately motivated by individual reasons. As a result, the exceeding number of asylum applicants could be interpreted as an individual initiative toward a tentative form of regularisation. The question becomes then to understand how the decision of stay as irregular migrant could be previously facilitated by external factors (i.e. by a large and well-established community of compatriots, economic opportunities in the informal labour market, lack of controls) and the reasons why these factors stopped limiting the attractiveness to choose for a legal status.

If Territorial Commissions keep the same monthly productive achieved during the first period of the year, around 95,000 decisions will be issued as annual amount. The 
decree of the Council of Ministers approved on 24 September 2018 repealed the protection status for humanitarian reasons. This form of protection was defined by the Consolidated Act of Immigration (article 5) to safeguard the rights of asylum seekers under particular circumstances, such as health or pregnancy conditions. In 2017, 25 out of 100 decisions issued by Territorial Commissions recognised a protection for humanitarian reasons; from January to August 2018, more than 16,600 immigrants granted this form of protection. Nevertheless, it should be noted that the other European Member States make a very limited use of any national forms for protection. Considering that this restrictive measure could significantly affect future decisions, around 59,600 of them (63\% rejection rate) are assumed to be negative in 2018 .

Based on the circular of the Ministry of Interior on 4 July 2018, claiming than more than 33,500 appeals were recorded during the first half of 2018, negative decisions at the second instance are expected to be around 12,000, appraising a similar share of rejected appeals and assuming similar composition and profiles of immigrants in comparison with 2017. Return measures are expected to confirm the enforcement reached in 2017 of 8850 rejected asylum seeker to be returned to their country of origin.

A final consideration should be addressed to the stock of pending cases at the end of the 2018; at the beginning of the year, 148,512 asylum seekers are estimated to wait for a decision; at the end of the year, which derives from the stock at the beginning of 2017, adding the applicants and subtracting the decision issued during the year, 107,547 are expected to remain waiting for a first instance asylum decision. It implies that, assuming as constant the monthly productivity (7892) performed by Territorial Commissions during the year, 13 months should be fully needed to deal with the already recorded asylum applicants.

The proposed scenario suggests the following implications:( a) at the end of year, approximately 37,500 failed asylum seekers might become irregular immigrants, and 28,712 immigrants could be added to the stock of irregular migrants that would live or could not leave Italy; (b) potential decreasing effects appear at play: the lesser the inflow of irregular immigrants, the larger the number of asylum seekers. These increase in asylum applicants turns into a possible, although modest (-1523), decrease of the stock of irregular migrants residing in Italy at the end of 2018.

\section{Assessing the nexus between asylum and irregular migration}

The relationship between asylum inflows and the stock of irregular migrants residing in Italy is summarised by the annual changes of the stock of irregular migrants residing in Italy from the base year 2015 to the end of 2018. According to ISMU Foundation (Table 1), around 404,000 immigrants should irregularly reside in Italy at the beginning of 2015; at the beginning of 2018, ISMU Foundation provides estimation of a stock of 533,000 irregular migrants (recording a total increase by 32\%); 10 out of 100 immigrants are irregular.

The Table 4 provides an overview of the estimated stock of migrant population in Italy compared with the estimation of irregular migrants carried out by the Ismu Foundation.

Specifically, (a) the estimation of irregular migrants under the label 'Low impacts' substantiates the hypothesis that immigrants, arrived in Italy irregularly and missed to 
Table 4 Irregular migrants residing in Italy: comparison between estimations

\begin{tabular}{|c|c|c|c|c|c|}
\hline \multirow[b]{2}{*}{ Year } & \multicolumn{3}{|c|}{ Migrant population in Italy -ISMU } & \multicolumn{2}{|c|}{ Asylum-related irregular migrants } \\
\hline & Total & Regular migrants & Irregular migrants & 1. Hypothesis & 2. Hypothesis \\
\hline & & & & High Impact & Low Impact \\
\hline 2015 & $5,819,000$ & $5,415,000$ & 404,000 & 494,500 & 426,000 \\
\hline 2016 & $5,871,000$ & $5,436,000$ & 435,000 & 578,200 & 451,900 \\
\hline 2017 & $5,958,000$ & $5,467,000$ & 491,000 & 605,600 & 468,600 \\
\hline 2018 & $6,108,000$ & $5,575,000$ & 533,000 & 634,300 & 467,000 \\
\hline
\end{tabular}

lodge their application for international protection, left the country; it implies that the annual irregular migrant inflow corresponds to rejected asylum seekers; (b) the estimation of irregular migrants under the label 'High impacts' represent the hypothesis that the annual inflow of irregular immigrants is composed by both those who arrived in Italy irregularly and missed to lodge their application for international protection in Italy, and rejected asylum seekers.

As findings from the analysis, the stock of irregular migrants in 2018 can fluctuate from 467,000 to 634,300 . In comparison with the 2015-base year, the increase is likely to vary from $16 \%$, according to hypothesis 'Low Impacts', to $57 \%$, according to hypothesis 'High Impacts'. As a consequence of the number of irregular immigrants, the share of irregular immigrant over the migrant population could differ from 8.3 to $10.7 \%$.

Analytically, the changes of the stock of irregular immigrants are measured as a proportion of asylum inflows (Table 5):

- At the end of 2015, 59 out of 100 immigrants arrived during the year became irregular, as results from the combination between the two subcategories of inflows: immigrants, who did not apply for international protection, and rejected asylum seekers who decided to remain in Italy as irregular immigrants. Under the hypothesis that immigrants, who arrived in Italy illegally and missed to lodge their application for international protection, left the country within the year, the proportion falls to $14 \%$ (14 out of 100 arrived immigrants became irregular);

- At the end of 2016, the proportion between inflows and the stock of irregular migrants could vary from $46 \%$, considering the two subcategories of irregular entries and failed asylum seekers as whole, to $14 \%$, computing only the effects of the rejected asylum seekers;

- At the end of 2017, the same proportion is estimated to change from $23 \%$, which is fully derived from the subcategory of the failed asylum seekers, to $14 \%$, also computing irregular immigrants who previously arrived in Italy and applied for international protection during the year;

- In 2018, a combined dynamics between inflows of irregular entries and asylum seekers could affect the stock of irregular migrants: possible deflection effects could result at the end of year by the transfer from irregular to legal status for more than 30,000 immigrants. However, the recent restrictiveness of asylum policies adopted by the Italian government (the repeal of protection for humanitarian reasons) might discourage potential asylum seekers in filing asylum applications in the future. 
Table 5 Estimation of annual flows linked with asylum procedure, method

\begin{tabular}{|c|c|c|}
\hline Asylum procedure & Description of events & Method \\
\hline \multirow[t]{3}{*}{ Identification } & Arrival and Eurodac check and registration & $A_{t}$ \\
\hline & Lodging of application & $S_{t}$ \\
\hline & Irregular immigrants after the identification procedure & $E_{t}=A_{t}-S_{t}$ \\
\hline \multirow[t]{4}{*}{ First instance procedure } & Examination and decision & \\
\hline & First instance total decisions & $D f_{t}$ \\
\hline & First instance positive decisions & $D p f_{t}$ \\
\hline & First instance negative decisions & $N f_{t}=D f_{t}-D p f_{t}$ \\
\hline \multirow[t]{5}{*}{ Second instance procedure } & Appeals against the first instance decision & $A p_{t}$ \\
\hline & Second instance decisions & $D s_{t}$ \\
\hline & Second instance positive decisions & $D p s_{t}$ \\
\hline & Second instance negative decisions & $N s_{t}=D s_{t}-D p s_{t}$ \\
\hline & Irregular immigrants after the second instance procedure & $R a_{t}=N f_{t}-A p_{t}+N s_{t}$ \\
\hline \multirow[t]{3}{*}{ Return } & Forced, assisted and volontary returnees & $R e_{t}$ \\
\hline & Estimated Irregular immigrants flow during the period & $I a_{t}=R a_{t}-R e_{t}$ \\
\hline & Estimated impact on irregular migrant stock & \\
\hline $\begin{array}{l}\text { 1. Hypothesis High Impact } \\
\text { 2. Hypothesis Low Impact }\end{array}$ & $\begin{array}{l}\text { Irregular immigrants remain in Italy } \\
\text { Irregular immigrants leave Italy }\end{array}$ & $\begin{array}{c}I m_{t}=E_{t}+I a_{t} \\
I m_{t}=I a_{t}\end{array}$ \\
\hline
\end{tabular}

\section{Conclusions}

This paper has provided an empirical analysis of the relationship between asylum inflows and irregular migration stocks in Italy. Findings from the analysis have shown that the decrease of irregular entries can be counter-balanced by an increase of failed asylum seekers that, under certain conditions, could generate, as sort of paradoxical consequence, the temporary increase of irregular migrant stock. This is the situation that may occur from 2018, when Territorial Commission should predominately deal with a pre-existing stock of asylum seekers waiting for a first instance decision. This combination of these effects should be an important caveat to rethink about the real short-term impacts of restrictive entry

The shift of irregular migrants to a legal status can be seen as a possible form of regularisation decided by individuals; only future analyses will be able to assess developments and implications of new trends. Currently, Italy continues to face the interlinked challenge between asylum and irregular migration. This challenge may appear less urgent today than in 2015-2016 because fewer irregular immigrants are now arriving; yet, there are motivations for stressing the urgency of a structural solution. The situation seems to be more associated with measures, such as the cooperation with the Libyan coast guard, with important outcomes in a short term, than with long-term sustainable actions. At European levels, the unsuccessful experiences in relocation programs have shown the weakness of the solidarity principle implementation.

Irregular migration often expresses the imbalance between the unlimited supply of emigration from the countries of origin and the limited reception capacities by the destination countries; reversing the trend should require legal opportunities to emigrate 
and legal opportunities for labour migration. But, entry and stay in irregular conditions is also an individual decision. In countries like the USA and Canada, which were created by immigration, irregular immigration is still representing an alternative entry procedure for those who do not meet the required criteria to be eligible for admissions. If returning irregular migrants to their home countries has been a key objective of European Union policies, rejected asylum seekers may choose to bear risks to live as irregular migrants in Europe anyway. This highlights that migration-specific policies cannot overcome migrants' perspective and raises key questions at the political, societal, and human rights level about how to best address this group, living in a state of continuous limbo and uncertainty.

Could irregular immigration be eliminated? The reply may be negative. Yet, in an ideal (maybe unrealistic?) world without restrictions on entering, residing or leaving a country, irregular immigration would be a concept without reference.

\section{Endnotes}

${ }^{1}$ https://eur-lex.europa.eu/legal-content/EN/TXT/PDF/?uri=CELEX: 52015DC0240\&from=EN (login: 30.09.2018) Specifically, the Agenda sets out four levels of action for an European migration policy, which includes: addressing the root causes of irregular and forced displacement in third countries.

${ }^{2}$ Dublin regulation (III, 2013)

${ }^{3}$ Nevertheless, if asylum applicant claims to be in or transited through another European Member State or to have some relatives in another European Member State, being able to provide evidence of the statement, the other Member State should take in charge of his/her request.

${ }^{4}$ European Asylum Procedure Directive (2013): to remain in the territory, including at the border or in transit zones, of the Member State in which the application for international protection has been made or is being examined.

${ }^{5}$ http://www.interno.gov.it/it/temi/immigrazione-e-asilo/modalita-dingresso (login: 23.09.2018) In general, Italian legislation affirms the rights of irregular migrants by the Immigrant Act, regardless of how they are present at the territory of the State, fundamental rights should be recognised. Italian Constitution (article 10) claims that the right of asylum and (article 13) states that the personal freedom is inviolable and detention should only be allowed by Law for judicial reasons.

${ }^{6}$ In 2015, the European Commission promoted the hot-spot approach as part of its Agenda on Migration. Hot-spots are located in frontline Member States, Italy and Greece, and they are defined to ensure that all immigrants irregularly arrived in the European Union are identified and registered, to support relocation programs or return procedures when applicable. Hotspots in Italy are regulated by the Ministry of Interior Roadmap which establishes that immigrants' permanence should not exceed 5 days. As of July 2017, hot-spots in Italy were Lampedusa, Pozzallo, Taranto and Trapani; then, the Ministry of Interior announced six additional hotspots: Palermo, Siracusa, Cagliari, Crotone, Reggio Calabria and Corigliano Calabro.

${ }^{7}$ However, there is a sort of administrative holding of irregular immigrants as a temporary condition in preparation of their repatriation (in the so called Centre for identification and expulsion, cfr also the Charter of rights and obligations of irregular 
immigrants in detention centres, Carta dei diritti e dei doveri dello straniero nei centri di Identificazione ed. Espulsione),

${ }^{8}$ Data source: http://www.ismu.org/wp-content/uploads/2018/03/XXIII-Report-onmigrations-2017-1.pdf

${ }^{9}$ They originated from Eritrea (25\%), Nigeria (14\%), Somalia (8\%), Sudan (6\%) and Syria (5\%).

${ }^{10}$ Main countries of origin were: Nigeria (21\%), Eritrea (11\%), Guinea (7\%).

${ }^{11}$ Data source: https://ec.europa.eu/home-affairs/financing/fundings/migration-asylum-borders/asylum-migration-integration-fund_en login 14.10.2018

${ }^{12}$ Data source: Eurostat, Asylum first time applicants in 28 European Member States plus Norway and Switzerland

${ }^{13}$ Frontex (the European Border and Coast Agency) claimed around 511.000 detections of illegal border-crossing the European Union Data source: Frontex 2017

${ }^{14}$ The share of positive decisions on the total number of decisions recorded by all 28 European Member States

${ }^{15} \mathrm{COM}$ (2015) 240, version dated 13.05.2015; The European Agenda on Migration was addressed to reducing the incentives for irregular migration, setting as one of the first levels of action for the European migration policy, the reduction of the incentives for irregular migration. Political Guidelines pointed out the need of a robust fight against irregular migration, traffickers and smugglers; securing Europe's external borders must be paired with a strong common asylum policy as well as a new European policy on legal migration, stepping up cooperation with the countries of origin and transit.

${ }^{16} \mathrm{LD} 142 / 2015$ clarifies that applications for international protection could be made in the territory, including at the border and in transit zones.

${ }^{17}$ Data source: migr_dubri login 14.10.2018

${ }^{18}$ More detailed analysis of immigrants' behaviours cannot be conducted in the lack of micro data sources.

${ }^{19}$ Monthly average of immigrants arrived in Italy was 2158, against 4519 asylum applicants recorded on average by Questure.

\section{Additional file}

Additional file 1: Workflow in the data collection by phase of asylum procedure from the arrival of immigrants to the second-instance decision (DOCX $341 \mathrm{~kb}$ )

Acknowledgements

The authors thank colleagues from the Joint Research Centre, Nikolaos Stilianakis and Jutta Thielen Del Pozo, who provided their feedback on an earlier version of the manuscript, although they may not agree with all of the interpretations/conclusions of this paper.

The authors would also thank the reviewers for their detailed suggestions; the revised manuscript has benefitted from their comments improving in clarity and its overall presentation.

The authors would also like to show their gratitude to the Dipartimento delle Libertà Civili of the Ministero dell'Interno, for sharing data on migration and asylum inflows.

Funding

No specific funding has been provided for the analysis. 


\section{Disclaimer}

The views and opinions expressed in this article are those of the authors and do not necessarily reflect the official policy or position. Assumptions made within the analysis are not reflective of the position of any institutional entity.

\section{Authors' contributions}

Both authors made substantial contributions to the conception and design, acquisition of data, and analysis and interpretation of data. Both authors read and approved the final manuscript.

\section{Competing interests}

This manuscript has not been published and is not under consideration for publication elsewhere. The authors declare that they have no competing interests.

\section{Publisher's Note}

Springer Nature remains neutral with regard to jurisdictional claims in published maps and institutional affiliations.

Received: 20 December 2018 Accepted: 8 April 2019

Published online: 03 May 2019

\section{References}

AIDA (2017). Asylum Information Database, Country report, Association for Legal Studies on Immigration, European Council on Refugees and Exiles.

Aleshkovskiy, I. A. (2014). Undocumented migration as the phenomenon of the globalized world, age of globalization. 2014 No2., 129-136.

Baio G., \& Blangiardo G. C. (2011). Centre sampling technique in foreign migration surveys: A methodological note. Journal of Official Statistics, 27(3), 451-446.

Baker, B. (2016). Estimates of the size and characteristics of the resident non-immigrant population in the United States: Fiscal year 2014. Office of Immigration Statistics, Policy Directorate, U.S. Department of Homeland Securi.

Clandestino, Country Report Italy (2009). Clandestino Project, Final Report, 23 November 2009.

Cyrus, N., \& Kovacheva, V. (2009). Undocumented Migration in Germany. In: A. Triandafyllidou (Ed.), Irregular Migration in Europe (pp. 125-144). Myths and Realities, Ashgate

Czaika, M., \& Haas, H. (2014). The Effect of Visa Policy on International Migration Dynamics, IMI Working Paper n. 89, Oxford, International Migration Institute.

Czaika, M., \& Hobolth, M. (2014). Deflection into Irregularity? The (Un)Intended Effects of Restrictive Asylum and Visa Policie, International Migration Institute Working Paper 84. Oxford, IMI.

Disney et al. (2005). Evaluation of existing migration forecasting methods and models, Report for the Migration Advisory Committee, ESRC Centre for Population Change, Southampton, 2015.

Dublin Regulation (2013). EU Regulation 604/2013, Dublin Regulation, Official Journal of the European Union

European asylum procedure directive (2013). EU Directive 2013/32/EU, Procedures for Granting and Withdrawing International Protection (recast), Official Journal of the European Union

Frontex (2017). Risk analysis for 2017, Frontex, ref. N. 2133/2017, www frontex.europa.eu. Accessed 18 Apr 2019

Hatton T.J. (2011). Seeking Asylum Trends and Policies in the OECD, Centre for Economic Policy Research, ISBN: 978-1907142-40-6.

Jandl, M., et al. (2008). Report on methodological issues, Clandestino Project, April 2008

Massey, D. S. \& Pren, K. A. (2012). Unintended consequences of US immigration policy: explaining the post-1965 surge from Latin America, Population and development review, n. 38(1), pp. 1-29.

Neumayer E. (2005). Asylum Recognition Rates in Western Europe: Their Determinants, Variation and Lack of Convergence, Journal of Conflict Resolution n.49, pp. 43-66.

Papademetriou, D.G. (2005). The global struggle with illegal migration: No end in sight. https://www.migrationpolicy.org/ article/global-struggle-illegal-migration-no-end-sight. Accessed 18 Apr 2019.

Pinkerton, C., McLaughlan, G., \& Salt, J. (2004). Sizing the Illegally Resident Population in the UK, Home Office: Report 58/04.

Tapinos, G. (1999). Clandestine immigration: Economic and political issues. In: OECD/Sopemi (1999), trends in international migration (pp. 229-251). OECD.

\section{Submit your manuscript to a SpringerOpen ${ }^{\circ}$ journal and benefit from:}

- Convenient online submission

- Rigorous peer review

- Open access: articles freely available online

- High visibility within the field

- Retaining the copyright to your article

Submit your next manuscript at $\boldsymbol{\nabla}$ springeropen.com 